\title{
Influence of nitrogen sources on the enzymatic activity and grown by Lentinula edodes in biomass Eucalyptus benthamii
}

\author{
Z. C. Pedria*, L. M. S. Lozano ${ }^{b}$, K. L. Hermann ${ }^{c}$, C. V. Helm , \\ R. M. Peralta and L. B. B. Tavares $^{f}$ \\ aPrograma de Pós-graduação, Universidade Regional de Blumenau - FURB, Rua São Paulo, 3250, \\ Itoupava Seca, CEP 89030-000, Blumenau, SC, Brazil \\ ${ }^{\text {b} D e p a r t a m e n t o ~ d e ~ E n g e n h a r i a ~ Q u i ́ m i c a, ~ U n i v e r s i d a d e ~ R e g i o n a l ~ d e ~ B l u m e n a u ~-~ F U R B, ~}$ \\ Rua São Paulo, 3250, Itoupava Seca, CEP 89030-000, Blumenau, SC, Brazil \\ 'Programa de Pós-graduação em Engenharia Ambiental, Universidade Regional de Blumenau - FURB, \\ Rua São Paulo, 3250, Itoupava Seca, CEP 89030-000, Blumenau, SC, Brazil \\ 'Empresa Brasileira de Pesquisa Agropecuária - EMBRAPA, Florestas, Rua Estrada da Ribeira, Km 111, \\ CEP 83411-000, Colombo, PR, Brazil \\ 'Universidade Estadual de Maringá - UEM, Avenida Colombo, 5790, CEP 87020-900, Maringá, PR, Brazil \\ fUniversidade Regional de Blumenau - FURB, Rua São Paulo, 3250, Itoupava Seca, \\ CEP 89030-000, Blumenau, SC, Brazil \\ *e-mail: zairachiodini@gmail.com
}

Received: February 19, 2014 - Accepted: March 27, 2014 - Distributed: November 30, 2015

(With 2 figures)

\begin{abstract}
Lignocellulose is the most abundant environmental component and a renewable organic resource in soil. There are some filamentous fungi which developed the ability to break down and use cellulose, hemicellulose and lignin as an energy source. The objective of this research was to analyze the effect of three nitrogen resources (ammonium sulfate, saltpetre, soybean) in the holocellulolitic activity of Lentinula edodes EF 50 using as substrate sawdust E. benthamii. An experimental design mixture was applied with repetition in the central point consisting of seven treatments $(T)$ of equal concentrations of nitrogen in ammonium sulfate, potassium nitrate and soybean. The enzymatic activity of avicelase, carboxymetilcellulase, $\beta$-glucosidase, xylanases and manganese peroxidase was determined. The humidity, $\mathrm{pH}$, water activity $\left(\mathrm{a}_{\mathrm{w}}\right)$ and qualitative analysis of mycelial growth in 8 times of cultivation were evaluated. The results showed negative effect on enzyme production in treatments with maximum concentration of ammonium sulfate and potassium nitrate. The treatments with cooked soybean flour expressed higher enzymatic activities in times of 3,6 and 9 days of culture, except in the activity of manganese peroxidase. The highest production was observed in the treatment with ammonium sulfate, and soybean (83.86 UI.L $\left.{ }^{-1}\right)$ at 20 days of cultivation.
\end{abstract}

Keywords: basidiomycetes, biomass, enzymes, design of experimental mixture.

\section{Influência das fontes de nitrogênio na atividade enzimática e crescimento de Lentinula edodes na biomassa Eucalyptus benthamii}

\begin{abstract}
Resumo
Lignocelulose é o componente mais abundante do meio ambiente e recurso orgânico renovável no solo. Alguns fungos filamentosos têm desenvolvido a habilidade de degradar e utilizar celulose, hemicelulose e lignina como fonte de energia. O objetivo deste trabalho foi analisar o efeito de três fontes de nitrogênio (sulfato de amônio, nitrato de potássio e farelo de soja) na atividade enzimática de Lentinula edodes EF 50 utilizando como substrato serragem de $E$. benthamii. Foi aplicado um planejamento experimental de mistura com três repetições no ponto central constituído de sete tratamentos $(\mathrm{T})$ de iguais concentrações em nitrogênio de sulfato de amônia, nitrato de potássio e farinha de soja cozida. Foram determinadas a atividade enzimática da avicelase, carboximetilcelulase, $\beta$-glicosidase, xilanases e manganês peroxidase. Foram avaliados o teor de umidade, $\mathrm{pH}$, atividade de água $\left(\mathrm{a}_{\mathrm{w}}\right)$ e análise qualitativa do crescimento micelial em 8 tempos de cultivo. Os resultados mostraram efeito negativo na produção das enzimas nos tratamentos com máxima concentração de sulfato de amônia e nitrato de potássio. Os tratamentos com farinha de soja cozida expressaram maiores atividades enzimáticas, nos tempos de 3, 6 e 9 dias de cultivo exceto na atividade do manganês peroxidase. A maior produção foi observada no tratamento com sulfato de amônia e farinha de soja cozida (83.86 UI.L ${ }^{-1}$ ) em 20 dias de cultivo.
\end{abstract}

Palavras-chave: basidiomicetos, biomassa, enzimas, planejamento experimental de mistura. 


\section{Introduction}

The increasing worldwide expansion of agro-industrial activity has generated a lot of lignocellulosic waste wood, forest (sawdust), agriculture (sugarcane bagasse, sugar cane, corn husks, banana pseudostem), municipal waste (paper) and various industrial wastes (Sánchez, 2009).

The lignocellulosic wastes are comprised of three cellulose, hemicelulose and lignin components. Cellulose is the most abundant molecule on Earth, forming a linear biopolymer connected by $\beta-1,4$ glycosidic bonds. Although, hemicellulose polymers are heterogeneous pentoses (xylose and arabinose) and hexoses. The lignin is characterized as a heterogeneous polymer, usually formed by aromatic compounds (alcohols), complicating the degradation of biomass (Percival et al., 2006).

Much research has been conducted in order to reuse the biomass (bagasse sugar cane, corn stover) in order to produce biofuels (ethanol), enzymes, and other metabolites. The organisms which are predominantly responsible for the degradation of lignocellulosic biomass are fungi, highlight the basidiomycetes (Rabinovich et al., 2004). The distribution of the biomass involves the formation of long polysaccharides chain, primarily cellulose, hemicellulose, and subsequent hydrolysis, which can be converted into ethanol by fermentation (Zhou and Ingram, 2000).

In Brazil there was considerable development in the sector of production of pulp from hardwood Eucalyptus spp., which will cause a higher increase of forest residues in the environment (Maki et al., 2009). Therefore, an alternative would be the use of this biomass as a source of carbon for high growth white-rot fungi Lentinula edodes, through solid state fermentation. This fungi plays a key role in the degradation of lignin (Mikiashvili et al., 2004).

Supplements containing carbohydrate and nitrogen are readily available and commonly added to the culture medium to improve the growth conditions and the excretion of the enzymes produced by fungi (Philippoussis et al., 2011). The aim of this study was to analyze the effect of three nitrogen sources (ammonium sulphate, potassium nitrate and soybean) in the lignocellulolitic activity of Lentinula edodes using sawdust as substrate E. benthamii.

\section{Material and Methods}

\subsection{Microorganism}

The fungus Lentinula edodes EF 50 was obtained from Collection of Work Technology Laboratory Non-timber Products from the Brazilian Agricultural Research - National Research Center for Forestry - EMBRAPA FORESTS (Colombo, PR, Brazil). The fungi culture was maintained on plates with medium Potato Dextrose Agar (PDA, HiMedia, India) and incubated at $25 \pm 1{ }^{\circ} \mathrm{C}$ for 7 days.

\subsection{Enzyme production}

The experiment was conducted at the Laboratory of Biochemical Engineering, at the Regional University of Blumenau, SC, Brazil. It weighed $30 \mathrm{~g}$ E. benthamii with a particle size less than $3 \mathrm{~mm}$ and $6 \mathrm{~g}$ bagasse of cassava was added. The substrates were supplemented with different nitrogen sources of ammonium sulfate, potassium nitrate and soybean flour cooked, and the proportion of nitrogen of $1 \%$ was calculated for each treatment (Table 1 ). The amount of water used was $50 \mathrm{~mL}$, using methods described by Hermann et al. (2013). Each substrate was autoclaved at $121^{\circ} \mathrm{C}, 1 \mathrm{~atm}$ for 15 minutes, and after they were inoculated with $1 / 6$ of the Petri plate of Lentinula edodes in PDA.

The inoculated flasks were incubated in an incubator at $25 \pm 1^{\circ} \mathrm{C}$ at $3,6,9,12,15,20,25$ and 30 days. Analysis were performed using humidity $(\%), \mathrm{pH}$, water activity $\left(\mathrm{a}_{\mathrm{w}}\right)$ (Hermann et al., 2013) and analysis of microbial growth (ASTM, 1990).

\subsection{Enzymatic activities}

Extraction of enzyme complex was performed by vacuum filtration. The extracts were centrifuged and stored at $4{ }^{\circ} \mathrm{C}$. The xylanases activity was determined by the amount of reducing sugars released from xylan "birchwood" as described by Bailey et al. (1992). The enzymatic assay was carried for 5 minutes, $0.9 \mathrm{~mL}$ of $1 \%$ xylan along with $0.1 \mathrm{~mL}$ of enzyme extract, the reducing sugars were measured by the method of 3,5 dinitrosalicylic (DNS) (Miller, 1959).

Endoglucanase and the exoglucanase activity were determined according to the technique described by Tanaka et al. (1981). The technique is to conduct the hydrolysis of a $0.44 \%$ solution of carboxymethylcellulose in sodium acetate buffer $0.05 \mathrm{M}, \mathrm{pH} 5.0$ activity to the

Table 1. Design experimental mixture.

\begin{tabular}{cccc}
\hline \multirow{2}{*}{ Treatments } & \multicolumn{3}{c}{ Sources Nitrogen } \\
\cline { 2 - 4 } & Ammonium Sulfate (\%) & Potassium Nitrate (\%) & Soybean (\%) \\
\hline 1 & 100 & 0 & 0 \\
2 & 0 & 100 & 0 \\
3 & 0 & 0 & 100 \\
4 & 0 & 50 & 50 \\
5 & 50 & 50 & 0 \\
6 & 50 & 0 & 50 \\
$7 *$ & 33 & 33 & 34 \\
\hline
\end{tabular}

*Repeating central point. 
fraction of carboxymethylcellulase (CMC) and a 1.1\% suspension of the same buffer, microcrystalline cellulose to the fraction avicelase. The reaction was initiated by addition of $0.9 \mathrm{~mL}$ enzyme extract in $1 \mathrm{~mL}$ solution for the Avicel and exoglucanase in $1 \mathrm{~mL}$ of CMC solution endoglucanase in order to proceeding the reaction for 60 minutes. The amount of reducing sugars was determined by the DNS method (Miller, 1959).

The activity of $\beta$-glucosidase or cellobiose was determined according to Wood and Garcia-Campayo (1990), where $1 \mathrm{~mL}$ of cellobiose solution of $0.53 \%$ (diluted in sodium acetate buffer $\mathrm{pH}$ 5.0) to which was added $1 \mathrm{ml}$ of the enzyme extract and incubated at $50{ }^{\circ} \mathrm{C}$ for 30 minutes. The reaction was ended by immersing the tubes in boiling water for 5 minutes and then transfered to a cold water bath. The produced glucose was determined using the kit based on the reaction of glucose oxidase-peroxidase by the GOD-POD method.

The activity of manganese peroxidase (EC 1.11.1.13), was determined by the modified method of Wariishi et al. (1992). A reaction mixture containing $0.4 \mathrm{~mL}$ of enzyme extract, $0.4 \mathrm{~mL}$ of Manganese sulfate $\mathrm{PA}\left(\mathrm{MnSO}_{4}\right) 10 \mathrm{nM}$, $2.8 \mathrm{~mL}$ of buffer $50 \mathrm{mM}$ sodium malonate $(\mathrm{pH} 4.5)$ and $0.4 \mathrm{~mL}$ of hydrogen peroxide $\mathrm{PA}\left(\mathrm{H}_{2} \mathrm{O}_{2}\right) 0.5 \mathrm{mM}$ was prepared. The oxidation of $\mathrm{MnSO}_{4}$ by $\mathrm{H}_{2} \mathrm{O}_{2}$ resulted in the formation of the complex Mn malonate which was monitored at a wavelength of $270 \mathrm{~nm}\left(\varepsilon=11.59 \mathrm{M}^{-1} \mathrm{~cm}^{-1}\right)$. The enzymatic activity was expressed as International Units per liter (UI.L $\left.{ }^{-1}\right)$, defined as the amount of enzyme required to oxidize $1 \mu \mathrm{M}$ of substrate per minute per liter of extract.

For enzyme tests, an enzyme activity unit (U) was defined as the amount of enzyme capable of liberating $1 \mu \mathrm{mol}$ of reducing sugars (glucose or xylose) per minute at $50{ }^{\circ} \mathrm{C}$ and the enzyme activity expressed in $\mathrm{U}_{\mathrm{mL}} \mathrm{mL}^{-1}$ $\left(\mathrm{U}=\mu \mathrm{mol} \cdot \mathrm{mL}^{-1} \cdot \mathrm{min}^{-1}\right)$.

Statistical analysis of the experimental mixing was performed by means of multivariate analysis. The model was simplified to exclude terms that were not considered statistically significant ( $p>0.05$ ) by analysis of variance (ANOVA). The quality of the polynomial equation was evaluated using the coefficient of determination $\mathrm{R}^{2}$. All analyses were performed using the software Statistic 7.0 (StatSoft Inc., Tulsa, OK, USA).

\section{Results}

The mixture analysis is an efficient technique of surface response methods, which are widely used in the optimization of culture media (Ye et al., 2010; Yin et al., 2009). The composition of the substrate is an important fact for growth and expression of fungi, especially nutrients containing nitrogen and carbon (Rughoonundun et al., 2012). Commercial culture media for fungi containing yeast extract or peptone are expressive considering protein production in large scale (Ye et al., 2010).

The treatments 1,2 and 5 were less efficient in production of the enzyme until the end of cultivation. The avicelase production of the enzyme treatment was significantly positive $6\left(51.86 \mathrm{U} \cdot \mathrm{mL}^{-1}\right)$, with only 6 days of cultivation (Figure 1). A mixture of ammonium sulfate and soybean in this treatment was significant $\left(\mathrm{R}^{2}=0.990\right)$ to express the highest activity. The values of the activity remained stable until $12^{\text {th }}$ day of culture. However, in the $6^{\text {th }}$ day of culture, there was a significant difference $(p<0.05)$ in the substrate with the maximum concentration of ammonium sulfate, potassium nitrate (100\%), and absence of cooked soybean flour $(0 \%)$, being this case observed as the lowest enzymatic activities.

The values obtained in all treatment time of 3 days were near 4.5 U.mL ${ }^{-1}$. Thus, treatments 1, 2 and 5 showed lower activities of CMC at all times. The average treatment 7 (central point) were $15.0 ; 19.0$ and 19.0 U.mL ${ }^{-1}$ for 6 , 9 and 12 days of culture, respectively. From the $20^{\text {th }}$ day of culture, there was a $10 \%$ reduction in the activities higher than other treatments. The greatest potential for the enzyme treatment was $6\left(24.61 \mathrm{U} \cdot \mathrm{mL}^{-1}\right)$ (Figure 1) at time of 6 days of culture, with a correlation coefficient $\left(\mathrm{R}^{2}=0.96\right)$. The absence of soybean in the treatments was a relevant factor to differ statistically activities, obtaining values near $1.6 \mathrm{U} . \mathrm{mL}^{-1}$.

The lowest rates of activities of $\beta$-glucosidase were observed in treatments 1,2 and 5 in all culture times. The fungus $L$. edodes had its greatest potential for treating $6\left(2.71 \mathrm{U} \cdot \mathrm{mL}^{-1}\right)$, followed by treatment of $7\left(2.64 \mathrm{U} \cdot \mathrm{mL}^{-1}\right)$ at time 6, 9 and 12 days (Figure 1). For this same period, the correlation factors presented $\mathrm{R}^{2}=0.92, \mathrm{R}^{2}=0.96$ and $\mathrm{R}^{2}=0.86$, respectively. There was a significant difference in treatment $6(\mathrm{p}<0.05)$ at the time of 9 days. Comparing mixtures of treatments, the absence soybean reduced enzyme activity at all times. It was observed that higher concentrations of ammonium sulfate (100\%) and potassium nitrate $(100 \%)$ decreased production of 2.60 to $0.80 \mathrm{U} \cdot \mathrm{mL}^{-1}$. The mixture was favorable treatment 7 for the production of the enzyme since the first day of cultivation. The higher values correspond to days 6,9 , and 12 days, with a reduction by the end of the experiment.

The activities of the treatments 1,2 and 5 were lower than those of other treatments, close to $0.65 \mathrm{U} \cdot \mathrm{mL}^{-1}$ until the end of cultivation. The highest xylanases activities were obtained in the treatments 6 (Figure 1) and 4 (2.0 and $1.86 \mathrm{U} \cdot \mathrm{mL}^{-1}$ ) respectively. These activities were observed at the $6^{\text {th }}$ and $9^{\text {th }}$ day of cultivation and only significant difference in activity in the absence of soybean, with correlation factor $\left(\mathrm{R}^{2}=0.97\right)$. The central point averages showed activities of $1.60 \mathrm{U} \cdot \mathrm{mL}^{-1}$ and these results were obtained on the $6^{\text {th }}$, $9^{\text {th }}$ and $12^{\text {th }}$ day of cultivation. After this period, there was a decrease in the activity of all treatments.

Initially, treatment 1 was inactive to manganese peroxidase, until the $30^{\text {th }}$ day of culture. In treatments 2 and 6 , activity was observed on the $3^{\text {rd }}$ until the $12^{\text {th }}$ day, with average values $\left(0.64\right.$ UI.L $\left.{ }^{-1}\right)$, which did not purportedly differentiate. Treatment 3 showed its greater activity on the $20^{\text {th }}\left(23.9\right.$ UI.L $\left.{ }^{-1}\right)$. From the $15^{\text {th }}$ day of culture until the $30^{\text {th }}$ day of culture, there was an increased production of the enzyme in the treatment 6 , when there was a statistical difference compared to the other treatments. The treatment 


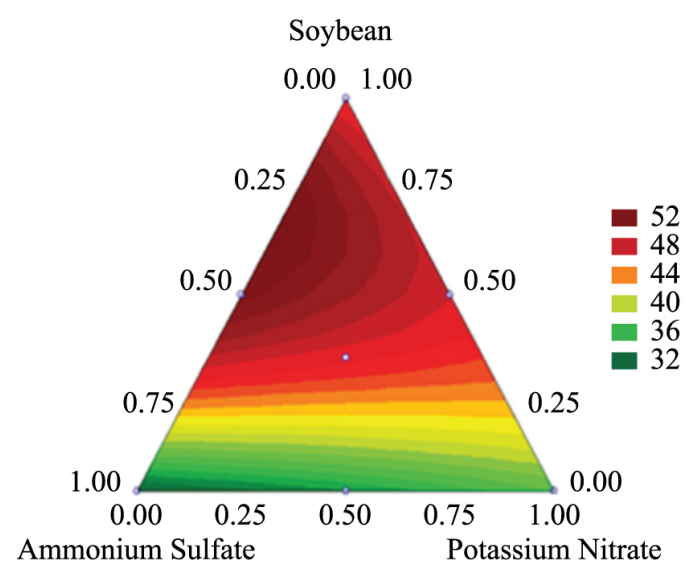

Avicelase (51.86 U.mL ${ }^{-1}$ )

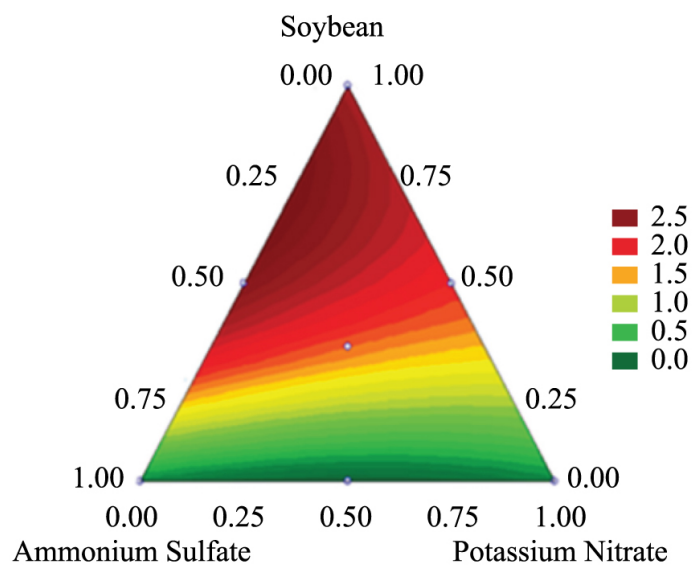

$\beta$-glucosidade (2.71 U.mL ${ }^{-1}$ )

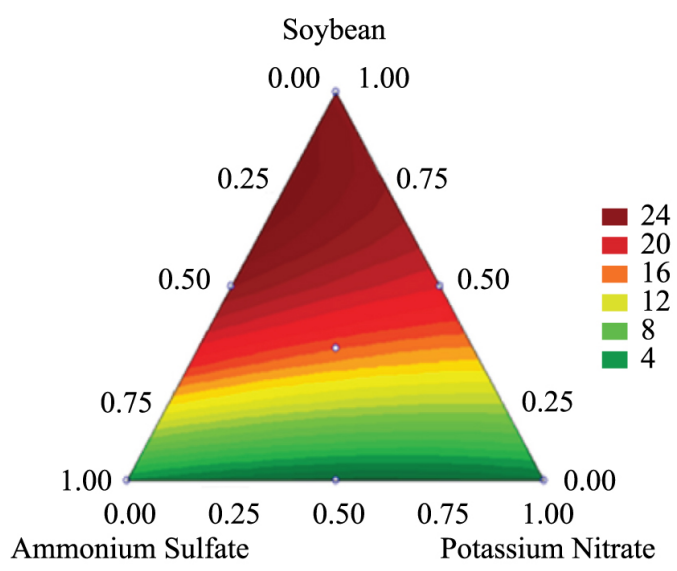

Carboxymetilcellulase (24.61 U.mL ${ }^{-1}$ )

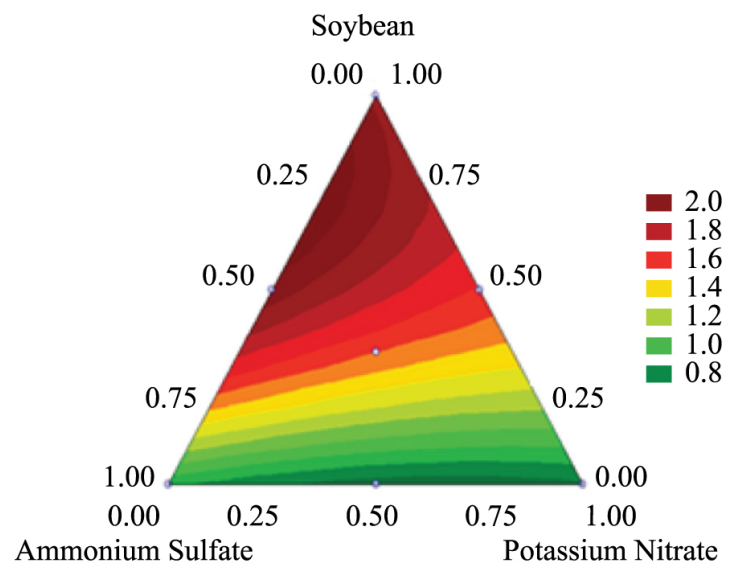

Xylanases (2.00 U.mL $\left.{ }^{-1}\right)$

Figure 1. Mixing contour plot of the variables ammonium sulfate, potassium nitrate and soybean in the maximum activity of four enzymes on EF 50 strain L. edodes in 6 days of culture.

7 showed an increased $5 \%$ production of the enzyme until $30^{\text {th }}$ day of cultivation. The activity of manganese peroxidase treatment 4 was superior to all treatments until the last day of culture, presenting activity 83.86 UI.L ${ }^{-1}$ on the $20^{\text {th }}$ of culture (Figure 2).

The results of humidity of all treatments showed mean values of $56 \%$, with no significant difference between treatments. From the $20^{\text {th }}$ day of culture, all the treatments showed a 5\% reduction in the percentage of humidity (Table 2).

According to Table 2, there was a reduction in $\mathrm{pH}$ treatments 1 and 2, containing ammonium sulfate and potassium nitrate. The higher initial $\mathrm{pH}$ value was observed on the third treatment, and contained the highest concentration of soybean. The treatments 3 and 4 showed values close to 5 and 6 and in last days we observed no significant increase.

The initial values of all treatments were higher than 0.990 (Table 2). According to the statistic there was no significant difference between treatments. The average central point

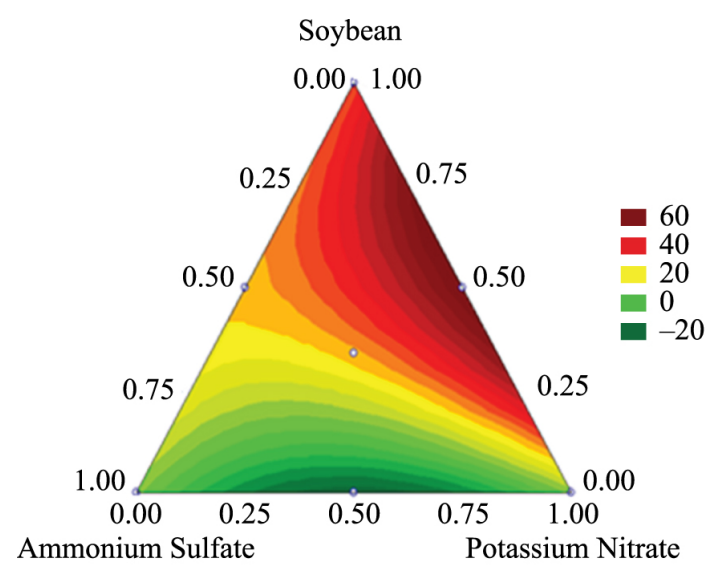

Manganese peroxidase (83.86 UI.L $\left.{ }^{-1}\right)$

Figure 2. Mixing contour plot of the variables ammonium sulfate, potassium nitrate and soybean in the maximum activity of manganese peroxidase on EF 50 strain L. edodes in 20 days of culture. 
Table 2. Humidity (\%), $\mathrm{pH}$ and water activity $\left(\mathrm{a}_{\mathrm{w}}\right)$ in different days.

\begin{tabular}{|c|c|c|c|c|c|c|c|c|c|}
\hline \multirow{2}{*}{$\begin{array}{c}\text { Humidity (\%) } \\
\text { Treatments }\end{array}$} & \multicolumn{9}{|c|}{ Days } \\
\hline & $\mathbf{0}$ & 3 & 6 & 9 & 12 & 15 & 20 & 25 & 30 \\
\hline 1 & 57.52 & 54.09 & 65.92 & 53.32 & 56.19 & 53.41 & 49.53 & 39.19 & 33.95 \\
\hline 2 & 56.12 & 59.26 & 58.78 & 53.33 & 52.01 & 52.56 & 45.37 & 41.18 & 41.69 \\
\hline 3 & 56.63 & 55.52 & 56.09 & 56.93 & 54.75 & 55.34 & 52.69 & 49.21 & 49.82 \\
\hline 4 & 56.37 & 57.66 & 55.57 & 56.03 & 55.93 & 54.01 & 51.56 & 49.80 & 48.00 \\
\hline 5 & 57.10 & 57.86 & 65.94 & 53.49 & 51.03 & 51.99 & 43.70 & 42.83 & 31.87 \\
\hline 6 & 57.64 & 55.36 & 57.71 & 56.22 & 52.59 & 50.04 & 50.14 & 47.78 & 43.88 \\
\hline $7 *$ & 56.37 & 54.58 & 57.41 & 54.62 & 51.32 & 59.53 & 49.00 & 44.76 & 42.06 \\
\hline pH & \multicolumn{9}{|c|}{ Days } \\
\hline Treatments & $\mathbf{0}$ & 3 & 6 & 9 & 12 & 15 & 20 & 25 & 30 \\
\hline 1 & 4.26 & 4.12 & 4.10 & 4.21 & 4.17 & 3.74 & 3.90 & 3.73 & 4.81 \\
\hline 2 & 4.21 & 4.07 & 4.05 & 4.17 & 4.13 & 3.75 & 4.17 & 3.85 & 4.64 \\
\hline 3 & 5.80 & 5.71 & 5.75 & 5.74 & 5.51 & 5.54 & 5.84 & 6.25 & 7.20 \\
\hline 4 & 5.20 & 5.02 & 5.21 & 5.00 & 5.54 & 5.18 & 5.77 & 6.05 & 6.90 \\
\hline 5 & 4.31 & 4.10 & 4.17 & 4.23 & 4.08 & 3.74 & 4.24 & 4.10 & 4.42 \\
\hline 6 & 5.37 & 4.65 & 4.86 & 4.57 & 4.41 & 4.63 & 4.99 & 5.08 & 6.27 \\
\hline $7 *$ & 4.93 & 4.68 & 4.78 & 4.59 & 4.33 & 4.04 & 4.47 & 4.86 & 5.51 \\
\hline $\mathbf{A}_{w}$ & \multicolumn{9}{|c|}{ Days } \\
\hline Treatments & $\mathbf{0}$ & 3 & 6 & 9 & 12 & 15 & 20 & 25 & 30 \\
\hline 1 & 0.995 & 0.991 & 0.993 & 0.985 & 0.983 & 0.989 & 0.983 & 0.976 & 0.961 \\
\hline 2 & 0.990 & 0.994 & 0.993 & 0.992 & 0.982 & 0.986 & 0.977 & 0.976 & 0.977 \\
\hline 3 & 0.998 & 1.003 & 0.997 & 0.997 & 0.993 & 0.996 & 0.994 & 0.993 & 0.987 \\
\hline 4 & 0.996 & 1.002 & 0.998 & 0.995 & 0.972 & 0.993 & 0.985 & 0.987 & 0.986 \\
\hline 5 & 0.992 & 0.997 & 0.998 & 0.997 & 0.982 & 0.993 & 0.978 & 0.977 & 0.983 \\
\hline 6 & 0.995 & 1.003 & 0.998 & 0.996 & 0.989 & 0.994 & 0.988 & 0.987 & 0.984 \\
\hline $7 *$ & 0.994 & 0.999 & 0.998 & 0.994 & 0.984 & 0.993 & 0.984 & 0.980 & 0.982 \\
\hline
\end{tabular}

*Repeating central point.

Table 3. Qualitative analysis of mycelial growth of Lentinula edodes EF 50.

\begin{tabular}{ccccccccc}
\hline \multirow{2}{*}{ Treatments } & \multicolumn{10}{c}{ Days } \\
\cline { 2 - 9 } & $\mathbf{3}$ & $\mathbf{6}$ & $\mathbf{9}$ & $\mathbf{1 2}$ & $\mathbf{1 5}$ & $\mathbf{2 0}$ & $\mathbf{2 5}$ & $\mathbf{3 0}$ \\
\hline 1 & - & + & + & - & - & - & - & - \\
2 & - & + & + & - & - & - & - & - \\
3 & + & ++ & ++ & +++ & +++ & +++ & +++ & +++ \\
4 & - & + & + & ++ & ++ & ++ & ++ & ++ \\
5 & + & - & - & - & - & - & - & - \\
6 & + & ++ & ++ & ++ & ++ & ++ & ++ & ++ \\
$7 *$ & + & + & + & + & + & + & + & + \\
\hline
\end{tabular}

(-) Without growth; (+) Partially mycelial growth in the medium; (++) Moderate growth with the appearance of "pellet" in the middle; (+++) Great growth of mycelial half of the whole flask. *Repeating of central point. Source: ASTM (1990).

(Treatment 7) showed more than 0.980 throughout in the incubation period. The highest activities were found on the $3^{\text {th }}$ day of culture in the treatments 3,4 and 6 .

The treatments 1, 2 and 5 showed no significant growth at all times (Table 3), only a small increase in the substrate at time 3 (treatment 5) and 9 time (treatments 1 and 2). The mycelial growth was similar in the moderate treatment 4 and 6. The fastest growth was observed in treatment 3 after 9 days of culture, with homogeneous colonization of hyphae in the substrate of sawdust.

\section{Discussion}

The activities of avicelase produced were greater than those obtained by Dinis et al. (2009), which reached its maximum output at 28 days of incubation. The presence of higher lignin concentrations in the structure directly affects the decomposition process by reducing the holocelulolitc activity (Berlin et al., 2006).

The treatments 1 and 2 were lower than found for Kachlishvili et al. (2006). In contrast, the activities of all 
treatments were superior to those obtained by Dinis et al. (2009), who reported their results in the maximum time of 14 days. The lowest activities were expressed in treatments with ammonium sulfate, potassium nitrate and mixture of these nitrogen sources. The ratio of nitrogen assimilated by fungus was favored with the presence of soybean in both treatments 3, 4 and 6, especially in the treatment 6 , with the combination of $50 \%$ soybean and $50 \%$ ammonium sulfate. Delabona et al. (2012), reported that the substrate containing soybean had maximal production of (CMC) 160 U.mL $\mathrm{mL}^{-1}$ with the fungus $A$. fumigatus in just 3 days of incubation.

The maximum values found for $\beta$-glucosidase was 2.71 U.mL $\mathrm{mL}^{-1}$ for treatment 6 in 6 days, and the results were superior to those of Silva et al. (2005). According Buswell et al. (1995) basidiomycetes have some capacity to produce both the oxidative and hydrolytic enzymes to degrade ligncellulosic susbtrates and most white rot fungi produce these enzymes in order to provide their adaptation to the extremely rich in lignocelluloses.

In this study xylanases activities were lower than those studies Silva et al. (2005) and Thakur et al. (2012) and superior to Chicatto et al. (2014). This activity was not significant for $L$. edodes compared with exo and endocellulases. Moyson and Verachtert (1991) showed that the decomposition of the substrate by L. edodes is initially associated with hemicellulose. Other studies have shown that the best fungal biomass and enzymes were obtained from sawdust with a high level of nitrogen, supplemented with $20 \%$ soybean (Silva et al., 2005). Hermann et al. (2013) obtained maximum activity for L. edodes (110 UI.L-1), in 10 days of cultivation. In contrast, in studies Dias et al. (2010), the peak production of MnP was on the $23^{\text {rd }}$ day of incubation, and lower values $\left(0.83\right.$ UI.L $\left.^{-1}\right)$ to those obtained in this study. The decrease in activity with increasing incubation time was possibly by the production of co-products or depletion of nutrients, thus inhibiting fungal growth and enzyme formation (Gupta et al., 2010). Previous studies have shown that organic sources greatly improved the production of enzymes (Dong et al., 2005) by $P$. ostreatus (Mikiashvili et al., 2006) as well as fungi L. edodes, $P$. chrysosporium in the activity of $\mathrm{MnP}$ (Kaal et al., 1995). Li et al. (2008) noted that the use of solid state fermentation of the enzymatic activities produced $\mathrm{MnP}\left(9.67\right.$ UI.L $\left.^{-1}\right)$ as compared to the liquid fermentation (0.044 UI.L $\left.{ }^{-1}\right)$ especially with agroindustrial residues, which allows the concentrated product (Liu et al., 2011). Hatakka (2001) reported that the degradation of lignin by L. edodes occurred during the secondary metabolism and nitrogen reached high levels of lignocellulosic degradation.

The correlation of enzyme activities indicated that the high potential of isolated metabolic activity and colonization of the substrate in the early days are essential to achieve the production of biomass (Philippoussis et al., 2011).

The humidity results were similar to the ones carried by Hermann et al. (2013), using the fungus L. edodes cultivated biomass of $E$. benthamii. The amount of water is limited to solid substrates which are critical in the formation of a water film on the surface, facilitating dissolution and transfer of nutrients and oxygen. However, the spaces among the particles must remain free to permit oxygen diffusion and heat dissipation (Sánchez, 2009).

The different nitrogen concentrations of the substrate modify the $\mathrm{pH}$ value, influencing the growth and production of metabolites (Przybylowicz and Donoghue, 1990). These results were similar to Ohga (1999) and Hermann et al. (2013), who found near $\mathrm{pH} 4.6$ during growth of L. edodes in sawdust. Studies have shown that L. edodes obtained higher mycelial growth at low pH (Furlan et al., 1997). Possibly the $\mathrm{pH}$ reduction contributed to the formation of aliphatic acids produced by white rot fungi in the fermentation (Hakala et al., 2005).

According to Hermann et al. (2013), the activity must have values above 0.890 for the occurrence of mycelial biomass production, and in these study the results proved ideal for the growth and metabolism of the fungus. It was observed that the highest values were observed in treatments 3, 4 and 6, which contained soybean component responsible for the availability of water for fungus.

In this study the treatments observed with ammonium sulfate and potassium nitrate did not favor the growth of the fungus throughout the day, as reported by Feng et al. (2010). Hyphae tip growth among filamentous fungi (ascomycetous and basidiomycetous fungi) is associated with an apical body and may, represent a system for polarized cell expansion (Higashitsuji et al, 2009). The high concentration of organic nitrogen mycelium allows or greater productivity, since this is necessary for the synthesis of proteins, nucleic acids and glucosamine as a major component of the cell wall. Mostly, the basidiomycetous fungi grow best in the presence of aminoacids (Leonowicz et al., 1990), differently inorganic nitrogen, when there was less exopolysaccharide and biomass. There are differences in the secretion and release of specific nitrogenase in the growth phase, the processing and use in source of nitrogen metabolism (Lee et al., 2004). Nitrogen may also be a limiting factor for microbial growth, include bacteria (Farjalla, et al., 2006). For the cultivation of $L$. edodes a source of nitrogen in this type of substrate, such as rice bran or wheat is required, as observed by Philippoussis et al. (2002). Many low molecular weight compounds have been identified in the cultivation of wood decomposing fungi. The mode of action of these compounds is to act directly on the plant cell wall or act as mediators of oxidative enzymes (Aguiar and Ferraz, 2011).

\section{Acknowledgements}

The authors would like to thank EMBRAPA - Empresa Brasileira de Pesquisa Agropecuária, CAPES, Coordenação de Aperfeiçoamento de Pessoal de Nivel Superior and CNPq, Conselho Nacional de Desenvolvimento Cientifico e Tecnológico.

\section{References}

AGUIAR, A. and FERRAZ, A., 2011. Mecanismos envolvidos na biodegradação de materiais lignocelulósicos e aplicações tecnológicas correlatadas. Quimica Nova, vol. 34, no. 10, pp. 1729-1738. 
AMERICAN SOCIETY FOR TESTING MATERIALS - ASTM, 1990. G21-90: standart practice for determinig resistence of plastics to fungi. West Conshohocken: ASTM.

BAILEY, M.J., BIELY, P. and POUTANEN, K., 1992. Interlaboratory testing of methods for assay of xylanase activity. Journal of Biotechnology, vol. 23, no. 3, pp. 257-270. http:// dx.doi.org/10.1016/0168-1656(92)90074-J.

BERLIN, A., BALAKSHIN, M., GILKES, N., KADLA, J., MAXIMENKO, V., KUBO, S. and SADDLER, J., 2006. Inhibition of cellulase, xylanase and beta-glucosidase activities by softwood lignin preparations. Journal of Biotechnology, vol. 125, no. 2, pp. 198-209. http://dx.doi.org/10.1016/j.jbiotec.2006.02.021. PMid:16621087.

BUSWELL, J.A., CAI, Y. and CHANG, S.T., 1995. Effect of nutrient nitrogen and manganese on manganese peroxidase and laccase production by Lentinula (Lentinus) edodes. FEMS Microbiology Letters, vol. 128, no. 1, pp. 81-88. http://dx.doi. org/10.1111/j.1574-6968.1995.tb07504.x.

CHICATTO, J.A., COSTA, A., NUNES, H., HELM, C.V. and TAVARES, L.B.B., 2014. Evaluation of hollocelulase production by Lentinula edodes (Berk.) Pegler during the submerged fermentation growth using RSM. Brazilian Journal of Biology = Revista Brasileira de Biologia, vol. 74, no. 1, pp. 243-250. http://dx.doi.org/10.1590/1519-6984.21712.

DELABONA, P.S., PIROTA, R.D.P.B., CODIMA, C.A., TREMACOLDI, C.R., RODRIGUES, A. and FARINAS, C.S., 2012. Using Amazon forest fungi and agricultural residues as a strategy to produce cellulolytic enzymes. Biomass and Bioenergy, vol. 37, pp. 243-250. http://dx.doi.org/10.1016/j.biombioe.2011.12.006.

DIAS, A.A., FREITAS, G.S., MARQUES, G.S.M., SAMPAIO, A., FRAGA, I.S., RODRIGUES, M.A.M., EVTUGUIN, D.V. and BEZERRA, R.M.F., 2010. Enzymatic saccharification of biologically pre-treated wheat straw with white-rot fungi. Bioresource Technology, vol. 101, no. 15, pp. 6045-6050. http:// dx.doi.org/10.1016/j.biortech.2010.02.110. PMid:20307975.

DINIS, M.J., BEZERRA, R.M.F., NUNES, F., DIAS, A.A., GUEDES, C.V., FERREIRA, L.M., CONE, J.W., MARQUES, G.S., BARROS, A.R. and RODRIGUES, M.A., 2009. Modification of wheat straw lignin by solid state fermentation with white-rot fungi. Bioresource Technology, vol. 100, no. 20, pp. 4829-4835. http://dx.doi.org/10.1016/j.biortech.2009.04.036. PMid:19450975.

DONG, J.L., ZHANG, Y.W., ZHANG, R.H., HUANG, W.Z. and ZHANG, Y.Z., 2005. Influence of culture conditions on laccase production and isozyme patterns in the white-rot fungus Trametes gallica. Journal of Basic Microbiology, vol. 45, no. 3, pp. 190198. http://dx.doi.org/10.1002/jobm.200410511. PMid:15902692.

FARJALLA, V.F., ENRICH-PRAST, A., ESTEVES, F.A. and CIMBLERIS, A.C.P., 2006. Bacterial growth and DOC consumption in a tropical coastal lagoon. Brazilian Journal of Biology $=$ Revista Brasileira de Biologia, vol. 66, no. 2A, pp. 383-392. http://dx.doi.org/10.1590/S1519-69842006000300002. PMID: 16862291

FENG, Y.L., LI, W.Q., WU, X.Q., CHENG, J.W. and MA, S.Y., 2010. Statistical optimization of media for mycelial growth and exo-polysaccharide production by Lentinus edodes and a kinetic model study of two growth morphologies. Biochemical Engineering Journal, vol. 49, no. 1, pp. 104-112. http://dx.doi. org/10.1016/j.bej.2009.12.002.

FURLAN, S.A., VIRMOND, L.J., MIERS, D.A., BONATTI, M., GERN, R.M.M. and JONAS, R., 1997. Mushroom strains able to grow at high temperatures and low $\mathrm{pH}$ values. World Journal of Microbiology \& Biotechnology, vol. 13, no. 6, pp. 689-692. http://dx.doi.org/10.1023/A:1018579123385.

GUPTA, A., GAUTAM, N. and MODI, D.R., 2010. Optimization of a-amylase production from free and immobilized cells of Aspergillus niger. Journal of Biotechnology and Pharmaceutical Research, vol. 1, no. 1, pp. 1-8.

HAKALA, T.K., LUNDELL, T., GALKIN, S., MAIJALA, P., KALKKINEN, N. and HATAKKA, A., 2005. Manganese peroxidases, laccases and oxalic acid from the selective whiterot fungus Physisporinus rivulosus grown on spruce wood chips. Enzyme and Microbial Technology, vol. 36, no. 4, pp. 461-468. http://dx.doi.org/10.1016/j.enzmictec.2004.10.004.

HATAKKA, A., 2001. Biodegradation of lignin. Biopolymers, no. 1 , pp. 129-180.

HERMANN, K.L., COSTA, A., HELM, C.V., LIMA, E.A. and TAVARES, L.B.B., 2013. Expression of manganese peroxidase by Lentinula edodes and Lentinula boryana in solid state and submerged system fermentation. Anais da Academia Brasileira de Ciências, vol. 85, no. 3, pp. 965-973. http://dx.doi.org/10.1590/ S0001-37652013000300009. PMid:24068086.

HIGASHITSUJI, Y., HERRERO, S., TAKESHITA, N. and FISCHER, $\mathrm{R} ., 2009$. The cell end marker protein TeaC is involved in growth directionality and septation in bjbAO03214. Eukaryotic Cell, vol. 8, no. 7, pp. 957-967. http://dx.doi.org/10.1128/EC.00251-08. PMid:19429780.

KAAL, J.E.E., FIELD, A.J. and JOYCE, W.T., 1995. Increasing ligninolytic enzyme activities in several white-rot Basidiomycetes by nitrogen-sufficient media. Bioresource Technology, vol. 53, no. 2, pp. 133-139. http://dx.doi.org/10.1016/0960-8524(95)00066-N.

KACHLISHVILI, E., PENNINCKX, M.J., TSIKLAURI, N. and ELISASHVILI, V., 2006. Effect of nitrogen source on lignocellulolytic enzyme production by white-rot basidiomycetes under solid-state cultivation. World Journal of Microbiology \& Biotechnology, vol. 22, no. 4, pp. 391-397. http://dx.doi. org/10.1007/s11274-005-9046-8

LEE, C.B., BAE, J.T., PYO, H.B., KIM, S.W., HWANG, H.J. and YUN, J.W., 2004. Submerged culture conditions for the production of mycelial biomass and exopolysaccharides by the edible Basidiomycete Grifola frondosa. Enzyme Microbiolgy, vol. 35, no. 5, pp. 369-376. http://dx.doi.org/10.1016/j.enzmictec.2003.12.015.

LEONOWICZ, A., WOJIAS-WASILEWSKA, M., ROGALSKI, J. and LUTEREK, J., 1990. Higher fungi as a potential feed and food source from lignocellulosic wastes. In: A. BLAŽEJ and V. PRÍVAROVÁ, eds. Environment biotechnology. New York: Elsevier, pp. 229-253

LI, L., LI, X.Z., TANG, W.Z., ZHAO, J. and QU, Y.B., 2008. Screening of a fungus capable of powerful and selective delignification on wheat straw. Letters in Applied Microbiology, vol. 47, no. 5, pp. 415-420. http://dx.doi.org/10.1111/j.1472-765X.2008.02447.x. PMid:19146531.

LIU, D., ZHANG, R., YANG, X., WU, H., XU, D., TANG, Z. and SHEN, Q., 2011. Thermostable cellulase production of Aspergillus fumigatus Z5 under solid-state fermentation and its application in degradation of agricultural wastes. International Biodeterioration \& Biodegradation, vol. 65, no. 5, pp. 717-725. http://dx.doi.org/10.1016/j.ibiod.2011.04.005

MAKI, M., LEUNG, K.T. and QIN, W., 2009. The prospects of cellulase-producing bacteria for the bioconversion of lignocellulosic 
biomass. The Journal of Biological Sciences, vol. 5, no. 5, pp. 500-516. http://dx.doi.org/10.7150/ijbs.5.500.

MIKIASHVILI, N., WASSER, S.P., NEVO, E. and ELISASHVILI, V., 2006. Effects of carbon and nitrogen sources on Pleurotus ostreatus ligninolytic enzyme activity. World Journal of Microbiology \& Biotechnology, vol. 22, no. 9, pp. 999-1002. http://dx.doi. org/10.1007/s11274-006-9132-6.

MIKIASHVILI, N., WASSER, S.P., NEVO, E., CHICHUA, D. and ELISASHVILI, V., 2004. Lignocellulolytic Enzyme Activities of Medicinally Important Basidiomycetes from Different Ecological Niches. International Journal of Medicinal Mushrooms, vol. 6, no. 1, pp. 63-72. http://dx.doi.org/10.1615/IntJMedMushr.v6.i1.70.

MILLER, G.L., 1959. Use of dinitrosalicylic acid reagent for determination of reducing sugar. Analytical Chemistry, vol. 31, no. 3, pp. 426-428. http://dx.doi.org/10.1021/ac60147a030.

MOYSON, E. and VERACHTERT, H., 1991. Growth of high fungi on wheat straw and their impact on the digestibility of the substrate. Applied Microbiology and Biotechnology, vol. 36, no. 3, pp. 421-424. http://dx.doi.org/10.1007/BF00208168.

OHGA, S., 1999. Evaluation of maturity by use of $\mathrm{pH}$ indicators in sawdust-based cultures ofLentinula edodes. Journal of Wood Science, vol. 45, no. 5, pp. 431-434. http://dx.doi.org/10.1007/ BF01177917.

PERCIVAL, Y.H., HIMMEL, M.E. and MIELENZ, J.R., 2006. Outlook for cellulase improvement: Screening and selection strategies. Biotechnology Advances, vol. 24, no. 5, pp. 452-481. http://dx.doi.org/10.1016/j.biotechadv.2006.03.003. PMid:16690241.

PHILIPPOUSSIS, A., DIAMANTOPOULOU, P. and ZERVAKIS, G., 2002. Monitoring of mycelial growth and fructification of Lentinula edodes on several agricultural residues. In: J.E. SÁNCHEZ, G. HUERTA and E. MONTIEL, eds. Mushroom biology and mushroom products. Cuernavaca: UAEM, pp. 279-287.

PHILIPPOUSSIS, A., DIAMANTOPOULOU, P., PAPADOPOULOU, K., LAKHTAR, H., ROUSSOS, S., PARISSOPOULOS, G. and PAPANIKOLAOU, S., 2011. Biomass, laccase and endoglucanase production by Lentinula edodes during solid state fermentation of reed grass, bean stalks and wheat straw residues. World Journal of Microbiology \& Biotechnology, vol. 27, no. 2, pp. 285-297. http://dx.doi.org/10.1007/s11274-010-0458-8.

PRZYBYLOWICZ, P. and DONOGHUE, J., 1990. Shiitake growers handbook: the art and science of mushroom cultivation. Dubuque: Kendall/Hunt Publishing Company.

RABINOVICH, M.L., BOLOBOVA, A.V. and VASIL'CHENKO, L.G., 2004. Fungal decomposition of natural aromatic structures and xenobiotics: a review. Applied Biochemistry and Microbiology, vol. 40, no. 1, pp. 1-17. http://dx.doi.org/10.1023/ B:ABIM.0000010343.73266.08.
RUGHOONUNDUN, H., MOHEE, R. and HOLTZAPPLE, M.T., 2012. Influence of carbon-to-nitrogen ratio on the mixedacid fermentation of wastewater sludge and pretreated bagasse. Bioresource Technology, vol. 112, pp. 91-97. http://dx.doi. org/10.1016/j.biortech.2012.02.081. PMid:22425518.

SÁNCHEZ, C., 2009. Lignocellulosic residues: biodegradation and bioconversion by fungi. Biotechnology Advances, vol. 27, no. 2, pp. 185-194. http://dx.doi.org/10.1016/j.biotechadv.2008.11.001. PMid:19100826.

SILVA, E.M., MACHUCA, A. and MILAGRES, A.M.F., 2005. Effect of cereal brans on Lentinula edodes growth and enzyme activities during cultivation on forestry waste. Letters in Applied Microbiology, vol. 40, no. 4, pp. 283-288. http://dx.doi. org/10.1111/j.1472-765X.2005.01669.x. PMid:15752219.

TANAKA, T., TANIGUCHI, M.A., MATSUMO, R. and KAMIKUBO, T., 1981. Purification and properties of cellulases from Eupenicillium javanicium. Journal of Fermentation Technology, vol. 59, no. 3, pp. 177-183.

THAKUR, S., SHRIVASTAVA, B., INGALE, S., KUHAD, R.C. and GUPTE, A., 2012. Degradation and selective ligninolysis of wheat straw and banana stem for an efficient bioethanol production using fungal and chemical pretreatment. Biotechonology, vol. 3, no. 5 , pp. $365-372$

WARIISHI, H., VALLI, K. and GOLD, M.H., 1992. Manganese(II) oxidation by manganese peroxidase from the basidiomycete Phanerochaete chrysosporium: kinetic mechanism and role of chelators. The Journal of Biological Chemistry, vol. 267, no. 33, pp. 23688-23695. PMid:1429709.

WOOD, T.M. and GARCIA-CAMPAYO, V., 1990. Enzymology of cellulose degradation. Biodegradation, vol. 1, no. 2, pp. 147161. http://dx.doi.org/10.1007/BF00058833.

YE, Q., LI, X., YAN, M., CAO, H., XU, L., ZHANG, Y., CHEN, Y., XIONG, J., OUYANG, P. and YING, H., 2010. High-level production of heterologous proteins using untreated cane molasses and corn steep liquor in Escherichia coli medium. Applied Microbiology and Biotechnology, vol. 87, no. 2, pp. 517-525. http://dx.doi.org/10.1007/s00253-010-2536-0. PMid:20309539.

YIN, H., CHEN, Z., GU, Z. and HAN, Y., 2009. Optimization of natural fermentative medium for selenium-enriched yeast by d-optimal mixture design. LWT - Food Science Technology, vol. 42, no. 1, pp.327-331. http://dx.doi.org/10.1016/j.1wt.2008.04.002.

ZHOU, S. and INGRAM, L.O., 2000. Synergistic hydrolysis of carboxymethyl cellulose and acid-swollen cellulose by two endoglucanases (CelZ and CelY) from Erwinia chrysanthemi. Journal of Bacteriology, vol. 182, no. 20, pp. 5676-5682. http:// dx.doi.org/10.1128/JB.182.20.5676-5682.2000. PMid:11004164. 